\title{
Standardization of Formulation for Development of Ginger Supplemented Confectionary Products
}

\author{
Manisha Kaushal*, Devina Vaidya, Ranjan Kaushik, Aarti, Anil Verma and Anil Gupta
}

Dept. of Food Science \& Technology, Dr. Y. S. Parmar University of Horticulture \& Forestry, Nauni, Solan, H.P. (173 230), India

\section{Corresponding Author}

Manisha Kaushal

e-mail: manishapht@gmail.com

\author{
Article History \\ Article ID: AR1849g \\ Received in $16^{\text {th }}$ October, 2017 \\ Received in revised form $20^{\text {th }}$ January, 2018 \\ Accepted in final form $25^{\text {th }}$ March, 2018
}

\begin{abstract}
Indian confectionery is one of the fastest growing sectors in the world with an estimated growth rate of $18-20 \%$ where India ranks $14^{\text {th }}$ globally. Today, with modern technology and continued growing interest in these products, large companies are competing to come up with the most interesting and novel products in the market. Ginger has a long history of use as a remedy and medicinal purposes due to its therapeutic and functional properties which were harnessed for the development of ginger appetizing tablets (gingoli) and ginger fruit bar. Gingoli was prepared by the wet granulation method, where the organoleptic acceptable formulation contained $25 \mathrm{~g}$ ginger powder in the standardized recipe with pear pak as binding agent. The granular formulation of ginger powder had characteristics preferable for tablet formation with Carr compressibility of $12.28 \%$, Hausner ratio 1.14 and an angle of repose as $27^{\circ}$. Further, among the different formulations for the development of ginger fruit appetized bar, ginger: plum 50:50 with 1.5\% appetizing mixture had highest acceptability scores with the dehydration ratio observed as $3.48: 1$ and moisture content of $12.64 \%$. Further, the supplementation of ginger for the preparation of ginger appetizing tablets and ginger fruit bar possessed significantly higher antioxidant activity, total phenols and crude fibre thus enhancing its functional properties and potentiality for market acceptability.
\end{abstract}

Keywords: Ginger, tablets, bar, antioxidant activity, formulation, organoleptic score

\section{Introduction}

Ginger (Zingiber officinale Roscoe) is a tropical monocotyledonous and herbaceous plant which belongs to the order Scitaminae and family Zingiberaceae (Okwuowulu, 1997). It is believed to be the native of South East Asia and is one of the important cash crop and principal spice all over the world (Purseglove et al., 1981). The total production of ginger in the world is 20,95, $056 \mathrm{t}$ from the total acreage of 3 , 22,157 ha (FAO, 2015), while in India the area and production of ginger is reported to be $1,50,000$ ha and 7,05,000 t, respectively (Anonymous, 2016). Ginger is widely used around the world in food as a spice both in fresh and dried form which adds flavour to the meal by creating spicy pungent taste (Jayashree et al., 2012). Ginger rhizome contains over 400 different functional compounds and the major constituents are carbohydrates, lipids, terpenes and phenols (Grzanna et al., 2005) where terpene components include zingiberene, $\beta$-bisabolene, $\alpha$-farnesene, $\beta$-sesquiphellandrene, and $\alpha$-curcumene, while phenolic compounds include gingerol, paradols, and shogaol responsible for characteristic odour and flavour of ginger. Besides these, amino acids, fiber, ash, protein, phytosterols, vitamins (e.g., nicotinic acid, vitamin A) and minerals are also present (Langner et al., 1998; Shukla and Singh, 2007) in appreciable amounts in ginger rhizome.

Ginger is a medicinal plant that has been widely used all over the world, since antiquity, for a wide array of unrelated ailments including arthritis, cramps, rheumatism, sprains, sore throats, muscular aches, pains, constipation, vomiting, hypertension, indigestion, dementia, fever and infectious diseases (Platel and Srinivasan, 2000; Mustafa and Srivastava, 1990). Ginger rhizome is typically consumed as a fresh or processed into paste, concentrate, dried ginger (sonth) or for flavouring tea (Sambisavam and Girija, 2006). Fresh ginger are perishable in nature and are spoiled due to improper handling, growth of spoilage microorganisms, susceptibility to rhizome rot, wilting and sprouting, action of naturally occurring enzyme, chemical reactions and structural changes during storage (Baranowski, 1985). Processing ginger into novel products will not only reduce perishability but will also increase storage stability (Pezzutti and Crapiste, 1997) apart from adding new products on market shelves. Indian confectionery is one of the fastest growing sectors in the world with an estimated growth rate of $18-20 \%$ where India ranks $14^{\text {th }}$ globally. The range of new fruit based confectionary products has jumped to 881 in 2003 from 232 in 1999 
(Nowakowski, 2000) due to health awareness among the people.

Thus, considering the functional properties of ginger, present study was undertaken to incorporate the ginger in preparation of confectionery products so as to harness its therapeutic properties apart from reducing postharvest losses and augmenting income to growers.

\section{Materials and Methods}

Ginger rhizome cv. Himgiri procured from experimental farm of Dr. Y. S. Parmar University of Horticulture and Forestry were thoroughly washed, peeled, sliced $(2 \mathrm{~mm})$ and blanched in a solution of $1.0 \%$ citric acid (Dhiman, 2015) before drying in mechanical dehydrator $\left(55 \pm 2{ }^{\circ} \mathrm{C}\right)$ to a moisture content below $10.00 \%$ (Jayashree et al., 2014). The dried slices were pulverizered into powder (Kaushal et al., 2017), sieved in 18 mesh/inch sieve and packed in polyethylene pouches for product development. The appetized ginger tablets (gingoli) were prepared by wet granulation method with varying concentrations of ginger powder $(0,5,10,15,20,25,30 \mathrm{~g})$ in the recipe (Table 1 ) and comparing three different binding agents whose TSS was maintained at $70^{\circ} \mathrm{B}$ each.

The ingredients (Table 1 ) after thorough mixing were sieved in $18 \mathrm{mesh} /$ inch sieve followed by drying at $55 \pm 2{ }^{\circ} \mathrm{C}$ for 2 hours to facilitate granulation. The ginger tablets were then prepared in Kambert Make 8 Station Mini Rotary Tablet Press Machine KMP-D-8 with a pressure of $9.8 \mathrm{kN}$ where the weight of each tablet was adjusted to $500 \mathrm{mg}$.

\begin{tabular}{lc}
\hline Table 1: Ingredients (R) for the preparation of gingoli \\
\hline Ingredients & Weight (g) \\
\hline Sugar powder & 30 \\
Anardana powder & 25 \\
Mango powder (Amchoor) & 5 \\
Common salt & 2 \\
Black salt & 2 \\
Fennel powder & 2 \\
Cumin powder & 2 \\
Mint powder & 2 \\
BINDING AGENT- hypertonic sugar syrup/ & 18 \\
gulkand/ osmotically dehydrated sand & \\
pear paste (pear pak) & \\
\hline
\end{tabular}

For the preparation of ginger fruit bar, the farm procured ginger rhizome and plum fruits were utilized for pulp extraction. The ginger pulp was extracted by the hot break method after adding 30.0\% water followed by heating for 60 minutes (Dhiman, 2015) and plum pulp was extracted by adding $10.0 \%$ water, heating for 15-20 minutes followed by passing the whole mass through the pulper. The pulp was preserved by heat pasteurization method (over-flow method) as advocated by Lal and Thakur (1978) and packed in presterilized glass bottles for its use in product development. Ginger fruit bar was prepared by mixing ginger and plum pulp in different proportions (100:0, 90:10, 80:20, 70:30, 60:40 and $50: 50)$ followed by homogenization and heating. The total soluble solid was raised to $25^{\circ} \mathrm{B}$ by exogeneous addition of cane sugar powder and the mixture was spread in a thin layer $(3-6 \mathrm{~mm})$ on the stainless steel trays $\left(30 \times 20 \mathrm{~cm}^{2}\right)$ with a tray load of $440 \mathrm{~g} \mathrm{tray}^{-1}$ and dried in a mechanical dehydrator at $55 \pm 2{ }^{\circ} \mathrm{C}$ to $13-14 \%$ moisture. The combinations of ginger plum bar were evaluated on the basis of sensory characteristics and the treatment with higher sensory score was further taken for the standardization of suitable concentration of appetizing mixture. The appetizing mixture prepared by mixing thyme seed powder ( $5 \mathrm{~g})$; mint powder (10 g); salt (10 g) and black salt (10 g) was tried in different concentrations of 1.0, 1.5, 2.0 and $2.5 \%$. The best treatment combination of ginger plum pulp with appetizing mixture was selected on the basis of sensory scores. Standardized ginger plum bar was cut into strips of $8 \mathrm{~cm}^{2}$ wrapped in a butter paper and packed in laminated aluminium pouches (150 g) prior to quality evaluation.

Physico-chemical analysis of fresh and processed products was conducted by using standard analytical procedures (Ranganna, 1997, AOAC, 2004). Total phenols were extracted in $80 \%$ ethanol and were estimated using FolinCiocalteau reagent (AOAC, 2004). The rate of dehydration per unit time was calculated by placing a weighed quantity of ginger slices or pulp on a stainless steel tray $\left(30 \times 20 \mathrm{~cm}^{2}\right)$ followed by drying in mechanical dehydrator $\left(55 \pm 2{ }^{\circ} \mathrm{C}\right)$ to a moisture content of $10-12 \%(w / w)$. Flow property of ginger powder was evaluated by using Carr compressibility (Carr, 1965) and Hausner Ratio (Hausner, 1967) and angle of repose (q) by fixed funnel method (Liu, 2011). In the funnel test, granular material was placed in a funnel and then is slowly deposited on a horizontal surface. The granular material moves over the face of the accumulated triangular pile. When the movement stops, the inclination of the pile represents the angle of repose. The inverse tangent of the ratio (height divided by half the width of the base of the pile) is the angle of repose (Liu, 2011).

The sensory evaluation of different formulations of confectionary products was done by a semi-trained panel of 7-9 judges for various quality attributes viz., colour, texture, flavour, taste and overall acceptability on 9 point hedonic scale for product standarization.

Data pertaining to sensory evaluation was statistically analyzed according to Randomized Block Design (RBD) as described by Mahony (1985) while, the data on chemical analysis was analyzed by following Completely Randomized Design (CRD) Cochran and Cox (1967).

\section{Results and Discussion}

\subsection{Physico-chemical characteristics}

The fresh ginger rhizome cv. Himgiri utilized for product 
development contained a moisture content of $82.39 \%$ with total soluble solids as $2.7^{\circ} \mathrm{B}$ (Table 2 ). The rhizomes were found to be a good source of total phenols (10.18 mg 100 $\left.\mathrm{g}^{-1}\right)$, antioxidant activity $(57.45 \%)$, crude protein $(2.73 \%)$, crude fibre (1.41\%) and total ash (1.66\%). These values were in conformity with the result reported by Abeyesekera et al. (2005), Sultan et al. (2005) and Shahid and Hussain (2012). Further, the plum fruits contribute $13.86^{\circ} \mathrm{B}$ total soluble solids with 2.94 per cent of acidity as malic acid, along with appreciable amount of ascorbic acid (18.30 mg $\left.100 \mathrm{~g}^{-1}\right)$, total phenols (96.66 mg $\left.100 \mathrm{~g}^{-1}\right)$, antioxidant activity (71.6\%), crude fibre $(0.07 \%)$ and total ash $(0.42 \%)$ which were in agreement to the values found by Erturk et al. (2009) and Esehaghbeygi et al. (2013). Thus, keeping view the nutritional properties of ginger and plum, they were suitably blended without the addition of exogenous colour, flavour and acid.

Table 2: Quality characteristics of fresh ginger rhizome (Zingiber officinale) and plum fruit (Prunus domestica)

\begin{tabular}{lcc}
\hline Characteristics & \multicolumn{2}{c}{ Mean \pm SD $^{*}$} \\
\cline { 2 - 3 } & Ginger rhizome & Plum \\
\hline Moisture (\%) & $2.7 \pm 0.10$ & $13.86 \pm 0.41$ \\
TSS ( ${ }^{\circ} \mathrm{B}$ ) & $0.15 \pm 0.02$ & $2.94 \pm 0.02$ \\
Titratable acidity (\% citric & $86.93 \pm 0.09$ \\
acid for ginger, \% malic & & \\
acid for plum) & & \\
pH & $1.26 \pm 0.02$ & $9.26 \pm 0.34$ \\
Total sugars (\%) & $8.48 \pm 0.53$ & $18.30 \pm 1.09$ \\
Ascorbic acid (mg $100 \mathrm{~g}^{-1}$ ) & $10.18 \pm 0.03$ & $96.66 \pm 2.89$ \\
Total phenols (mg $100 \mathrm{~g}^{-1}$ ) & $57.45 \pm 0.60$ & $71.6 \pm 0.55$ \\
Antioxidant activity $(\%)$ & $2.73 \pm 0.06$ & $0.6 \pm 0.06$ \\
Crude Protein (\%) & $1.41 \pm 0.02$ & $0.07 \pm 0.01$ \\
Crude fibre (\%) & $1.66 \pm 0.02$ & $0.42 \pm 0.03$ \\
\hline Total ash (\%) &
\end{tabular}

*All values are the mean of 10 observations

Perusal of data in Table 3 regarding physico-chemical characteristics of ginger powder (Table 3 ) indicated water absorption index, per cent water solubility index and bulk density of ginger powder as $0.79,14.00 \%$ and 0.50 respectively. The water activity of ginger powder was observed as 0.356 with crude fat as $5.73 \%$ and crude protein as $6.63 \%$. Further, the level of total phenols and antioxidant activity in ginger powder was found to be $243.86 \mathrm{mg} 100 \mathrm{~g}^{-1}$ and $83.73 \%$, respectively. The flow properties indicate that the ginger powder had a Carr compressibility of $12.28 \%$ and Hausner ratio of 1.14 , which categorizes ginger powder as good while the angle of repose was observed as $27^{\circ}$ thus putting it in excellent category according to the classification given by US Pharmacopeia (2016). Thus, the flow properties
Table 3: Physico-chemical characteristics of ginger powder (Zingiber officinale)

\begin{tabular}{lc}
\hline Parameters & Mean $\pm \mathrm{SD}^{*}$ \\
\hline Water absorption index & $0.79 \pm 0.02$ \\
Per cent water solubility index & $14.00 \pm 0.01$ \\
Bulk density $\left(\mathrm{g} \mathrm{m}^{-1}\right.$ ) & $0.50 \pm 0.01$ \\
Moisture content (\%) & $7.05 \pm 0.62$ \\
Water activity (aw) & $0.356 \pm 0.004$ \\
Total phenols (mg $\left.100 \mathrm{~g}^{-1}\right)$ & $243.86 \pm 0.06$ \\
Antioxidant activity (\%) & $83.73 \pm 0.04$ \\
Crude fat (\%) & $5.73 \pm 0.05$ \\
Crude protein (\%) & $6.63 \pm 0.61$ \\
Crude fibre (\%) & $10.11 \pm 0.03$ \\
Ash content (\%) & $5.33 \pm 0.03$ \\
Carr compressibility (\%) & 12.28 (Good) \\
Hausner ratio & 1.14 (Good) \\
Angle of repose & $27^{\circ}$ (Excellent) \\
\hline
\end{tabular}

${ }^{*}$ All values are the mean of 10 observations

of ginger powder clearly shows that ginger powder has properties suitable for tablet formation

\subsection{Ginger appetizing tablets (gingoli)}

The tablets prepared by using different concentrations of ginger powder (0-30\%) with a pre-standardized recipe $(R)$ bound with hypertonic sugar solution were subjected to sensory evaluation to find out the most palatable formulation.

Among the different combinations, significantly higher scores for colour, texture, aroma, taste and overall acceptability were scored by treatment combination $\mathrm{T}_{5} \mathrm{R}$ viz., $25 \mathrm{~g}$ ginger powder in the recipe $\mathrm{R}$ (Figure 1). On further screening of

- Colour - Texture - Aroma - Test - Overall acceptability

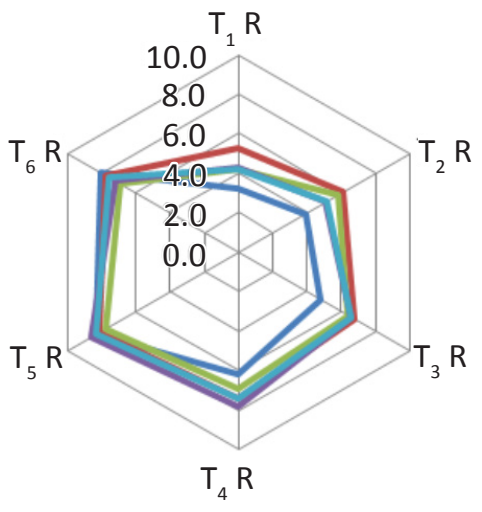

$\mathrm{T}_{1}: 5 \mathrm{~g}, \mathrm{~T}_{2}: 10 \mathrm{~g}, \mathrm{~T}_{3}: 15 \mathrm{~g}, \mathrm{~T}_{4}: 20 \mathrm{~g}, \mathrm{~T}_{5}: 25 \mathrm{~g}, \mathrm{~T}_{6}: 30 \mathrm{~g}$ ginger powder in recipe $R$

Figure 1: Sensory scores of ginger appetizing tablets with varying ginger concentration 
binding agents (Figure 2 ) the tablet bound by gulkand $\left(70^{\circ} \mathrm{B}\right)$ and pear pak $\left(70^{\circ} \mathrm{B}\right)$ were preferred over hypertonic sugar solution $\left(70^{\circ} \mathrm{B}\right)$ by the panelists with an overall acceptability scores of 8.3 and 8.7 respectively. This may be due to the presence of inherent biological content as fibre, sugar, phenols and vitamins etc. thus facilitating good compaction. Tavakoli et al. (2008) also reported that the type and amount of binders decisively influences the characteristics of the tablets prepared by wet granulation procedure. Thus a formulation having $25 \mathrm{~g}$ ginger powder in recipe $\mathrm{R}$ with pear pak as binding agent has been optimized and packed in aluminium laminated pouches for quality evaluation.

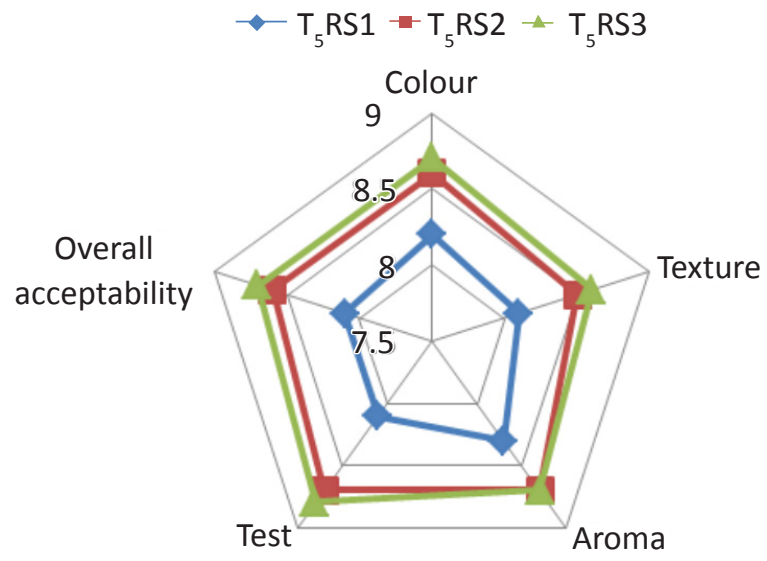

$\mathrm{S}_{1}$ : Hypertonic sugar solution; $\mathrm{S}_{2}$ : Gulkand; $\mathrm{S}_{3}$ : pear pak

Figure 2: Sensory scores of ginger appetizing tablets with different binding agents

\subsection{Quality characteristics of ginger appetizing tablets (gingoli)}

Data from the organoleptic evaluation clearly shows that 25 g ginger powder in recipe $\mathrm{R}$ (Table 4) binded with pear par (osmotically dehydrated sand pear paste) was liked by the panelists. Nutritionally the tablet contained $188.16 \mathrm{mg}_{100 \mathrm{~g}^{-1}}$ of total phenols, $89.76 \%$ of antioxidant activity, $7.44 \%$ crude fibre and $6.11 \%$ ash content with a water activity of 0.361 .

\subsection{Ginger plum bar}

Among the different pulp combinations, significantly higher scores for colour (8.25), texture (8.20), flavour (7.99), taste

Table 4: Physico-chemical characteristics of ginger appetizing tablets

\begin{tabular}{lc}
\hline Parameters & Mean \\
\hline Water activity (aw) & $0.361 \pm 0.002$ \\
Titratable acidity (\%) & $0.29 \pm 0.04$ \\
Total phenols (mg $\left.100 \mathrm{~g}^{-1}\right)$ & $188.16 \pm 0.91$ \\
Antioxidant activity (\%) & $89.76 \pm 0.79$ \\
Crude fibre (\%) & $7.44 \pm 0.12$ \\
Ash content (\%) & $6.11 \pm 0.05$ \\
\hline
\end{tabular}

(8.00) and overall acceptability (8.50) was received by ginger: plum 50:50 proportion (Table 5). The bar prepared by using $100 \%$ ginger was rated as least preferred with colour, texture, flavour, taste and overall acceptability scores of 5.16, 5.07,

Table 5: Sensory evaluation of recipes for the preparation of ginger plum bar

\begin{tabular}{lcccccc}
\hline $\begin{array}{l}\text { Treat- } \\
\text { ments }\end{array}$ & $\begin{array}{c}\text { Plum: } \\
\text { ginger } \\
\text { ratio }\end{array}$ & $\begin{array}{c}\text { Co- } \\
\text { lour }\end{array}$ & $\begin{array}{c}\text { Tex- } \\
\text { ture }\end{array}$ & $\begin{array}{c}\text { Fla- } \\
\text { vour }\end{array}$ & Taste & $\begin{array}{c}\text { Overall } \\
\text { accept- } \\
\text { ability }\end{array}$ \\
\hline $\mathrm{T}_{1}$ & $100: 0$ & 7.98 & 7.80 & 7.59 & 7.59 & 7.78 \\
$\mathrm{~T}_{2}$ & $90: 10$ & 8.10 & 7.82 & 7.62 & 7.62 & 7.87 \\
$\mathrm{~T}_{3}$ & $80: 20$ & 8.14 & 7.87 & 7.68 & 7.78 & 7.89 \\
$\mathrm{~T}_{4}$ & $70: 30$ & 8.16 & 7.98 & 7.76 & 7.81 & 7.92 \\
$\mathrm{~T}_{5}$ & $60: 40$ & 8.20 & 8.16 & 7.92 & 7.91 & 8.00 \\
$\mathrm{~T}_{6}$ & $50: 50$ & 8.25 & 8.20 & 7.99 & 8.00 & 8.50 \\
$\mathrm{~T}_{7}$ & $0: 100$ & 5.16 & 5.07 & 5.21 & 5.81 & 5.11 \\
$\mathrm{CD}$ & 0.04 & 0.03 & 0.02 & 0.08 & 0.03 & \\
$(p=0.05)$ & & & & & & \\
\hline
\end{tabular}

$5.21,5.81$ and 5.11 respectively with unacceptable pungency and further could not form into bar.

\subsection{Drying behaviour}

It took about 8.00 to 9.30 hours to dry the pulp combination to moisture content of about 13.04 to $13.93 \%$ (Table 6$)$. The dehydration ratio varied between $3.48: 1$ to $3.91: 1$ and the maximum yield ( $28.76 \%$ ) was noticed in $50: 50$ proportion and time taken for drying was 9.30 hours.

Table 6: Drying characteristics of ginger plum pulp formulation

\begin{tabular}{|c|c|c|c|c|c|c|}
\hline $\begin{array}{l}\text { Treat- } \\
\text { ments }\end{array}$ & $\begin{array}{l}\text { Plum: } \\
\text { ginger } \\
\text { pulp }\end{array}$ & DT & $\begin{array}{l}\text { Yield } \\
(\%)\end{array}$ & $\begin{array}{c}\text { Dehy- } \\
\text { dration } \\
\text { ratio }\end{array}$ & TS & $\begin{array}{c}\text { Moisture } \\
\text { (\%) }\end{array}$ \\
\hline $\mathrm{T}_{1}$ & 100: 0 & 8.00 & 27.10 & 3.91: 1 & 86.07 & 13.93 \\
\hline $\mathrm{T}_{2}$ & 90: 10 & 8.10 & 27.23 & $3.67: 1$ & 86.37 & 13.63 \\
\hline $\mathrm{T}_{3}$ & 80: 20 & 8.35 & 27.55 & 3.63: 1 & 86.59 & 13.41 \\
\hline $\mathrm{T}_{4}$ & 70: 30 & 8.55 & 28.21 & 3.55: 1 & 86.72 & 13.28 \\
\hline $\mathrm{T}_{5}$ & $60: 40$ & 9.15 & 28.70 & 3.48: 1 & 86.89 & 13.15 \\
\hline $\mathrm{T}_{6}$ & 50: 50 & 9.30 & 28.76 & 3.48: 1 & 86.99 & 13.04 \\
\hline \multicolumn{7}{|c|}{ DT: Drying time (hrs); TS: Total solids (\%) } \\
\hline \multicolumn{7}{|c|}{$\begin{array}{l}\text { To workout the optimum concentration of appetizing mixture } \\
\text { in the standardized pulp combination, results in Table } 7 \\
\text { showed that plum: ginger } 50: 50 \text { with } 1.5 \% \text { appetizing mixture } \\
\text { scored higher scores for colour ( } 7.40) \text {, texture (8.16), flavour } \\
\text { (7.90), taste ( } 7.97) \text { and overall acceptability (8.46) among all } \\
\text { combinations. }\end{array}$} \\
\hline
\end{tabular}




\subsection{Quality characteristics of ginger plum bar}

The data presented in Table 7 shows that the appetized ginger plum bar contains slightly higher amount of ascorbic acid (13.16 mg $100 \mathrm{~g}^{-1}$ ), phenols (55.89 mg $\left.100 \mathrm{~g}^{-1}\right)$, antioxidant activity $(72.94 \%)$ as compared to bar without appetizing mixture. Thus, the appetizing mixture $(1.5 \%)$ adds additional value to ginger plum bar.

Table 7: Effect of different concentrations of appetizing mixture on sensory quality of spiced plum ginger leather

\begin{tabular}{lcccccc}
\hline $\begin{array}{l}\text { Treat- } \\
\text { ments }\end{array}$ & $\begin{array}{c}\text { Plum: } \\
\text { ginger+ } \\
\text { *AM (\%) }\end{array}$ & $\begin{array}{c}\text { Co- } \\
\text { lour }\end{array}$ & $\begin{array}{c}\text { Tex- } \\
\text { ture }\end{array}$ & $\begin{array}{c}\text { Fla- } \\
\text { vour }\end{array}$ & $\begin{array}{c}\text { Taste } \\
\text { Overall } \\
\text { Accept- } \\
\text { ability }\end{array}$ \\
\hline $\mathrm{TA}_{1}$ & $50: 50+1.0$ & 7.36 & 7.94 & 7.86 & 7.88 & 7.62 \\
$\mathrm{TA}_{2}$ & $50: 50+1.5$ & 7.40 & 8.16 & 7.90 & 7.97 & 8.46 \\
$\mathrm{TA}_{3}$ & $50: 50+2.0$ & 7.18 & 7.68 & 7.68 & 7.58 & 7.58 \\
$\mathrm{TA}_{4}$ & $50: 50+2.5$ & 7.13 & 7.62 & 7.64 & 7.47 & 7.42 \\
$\mathrm{CD}$ & 0.03 & 0.02 & 0.05 & 0.14 & 0.08 & \\
$(p=0.05)$ & & & & & & \\
\hline
\end{tabular}

*AM: Appetizing mixture

\section{Conclusion}

Ginger possessing substantial nutritional properties can successfully be utilized for the preparation of ginger appetizing tablets and fruit bar. The ginger supplementation not only enhanced the nutritional value of the confectionary products but also created novel products for the market. Thus, the commercial adoption of this technology seems to be a profitable venture for utilization of ginger thereby augmenting the income of ginger growers with minimum postharvest losses.

\section{References}

Abeysekera, W.K.S.M., Illeperuma, C.K., Amunugoda, P.N.R.J., Wijeratnam, S.W., 2005. Comparison of ginger varieties dried at different temperatures for oil and oleoresin contents. Srilankan Journal of Agriculture Science 42, 34-42.

Anonymous, 2016. Agriculture and Statistics. Department of Agriculture, Co-operation and farmers welfare, Directorate of Economics and Statistics, New Delhi.

AOAC, 2004. Official methods of analysis of the association of official analytical chemist. In: Hortwits, W. (Ed.), Association of Official Analytical Chemists, Washington, D. C. US.

Baranowski, J.D., 1985. Storage stability of processed ginger paste. Journal of Food Science 50, 932-933.

Carr, R.L., 1965. Evaluating flow properties of solids. Chemical Engineering Journal 72, 69-72.

Cochran, W.G., Cox, C.M., 1987. Experimental Designs. John Wiley and Sons, Inc., New York, 1874.
Dhiman, A., 2015. Development and evaluation of novel products from ginger (Zingiber officinale), M.Sc. Thesis, Department of Food Science and Technology, Dr. Y.S. Parmar University of Horticulture and Forestry, Solan, 115.

Erturk, Y., Ercisli, S., Tosun, M., 2009. Physico-chemical characteristics of wild plum fruits (Prunus spinosa L.). International Journal of Plant Production 3(3), 89-92.

Esehaghbeygi, A., Pirnazari, K., Kamali, M., Razavi, J., 2013. Physical, and mechanical properties of three plum varieties (Prunus domestica L.). Thailand Journal of Agricultural Science 46(2), 95-101.

FAO, 2015. Total ginger production in the world. http://www. fao.org [10:30 AM, 20 $0^{\text {th }}$ March 2017]

Grzanna, R., Lindmark, L., Frondoza, C.G., 2005. Ginger- an herbal medicinal product with broad anti-inflammatory actions. Journal of Medicinal Food 8(2), 125-132.

Hausner, H.H., 1967. Friction conditions in a mass of metal powder. International Journal of Powder Metallurgy 3, 7-13.

Jayashree, E., Visvanathan, R., John, Z.T., 2014. Quality of dry ginger (Zingiber officinale) by different drying methods. Journal of Food Science and Technology 51, 3190-3198.

Kaushal, M., Dhiman, A., Gupta, A., Vaidya, D., Gupta, M., 2017. Postharvest management and value addition of ginger (Zingiber officinale Roscoe): a review. International Journal of Environment, Agriculture and Biotechnology 2, 389-396.

Lal, B.B., Thakur, D.R., 1978. Effect of NAA and 2, 4, 5-T on thinning and quality of Santa Rosa plum. Journal of Horticulture Science 7(2), 21-24.

Langner, M., Gabreiska, J., Kleszczynska, H., Pruchnik, H., 1998. Effect of phenyltin compounds on lipid bilayer organization. Applied Organometallic Chemistry 12(2), 99-107.

Liu, Z., 2011. Measuring the angle of repose of granular systems using hollow cylinders. M.Sc. Thesis, Department of Civil and Environmental Engineering. University of Pittsburgh, 61.

Mahony, M.O., 1985. Sensory evaluation of food. In: Statistical Methods and procedures. Marcel Dekker, Inc., New York.

Mustafa, T., Srivastava, K.T., 1990. Ginger (Zingiber officinale) in migraine headache. Journal of Ethnopharmacology 29, 267-273.

Nowakowski, C.M., 2000. Effect of corn syrups on stability of amorphous sugar products. Ph.D. Dissertation, University of Wisconsin, Madison, WI.

Okwuowulu, P.A., 1997. Ginger (Zingiber officinale): update in its production and challenges for the future. African Journal of Root and Tuber Crops 3, 7-11.

Pezzutti, A., Crapiste, G.H., 1997. Sorptional equilibrium and drying characteristics of garlic. Journal of Food Engineering 3, 113-123. 
Platel, K., Srinivasan, K., 2000. Influence of dietary spices and their active principles on pancreatic digestive enzymes in albino rats. Nahrung 1, 42-46.

Purseglove, J.W., Brown, E.G., Green, C.L., Robbins, S.R.J., 1981. Ginger. In: Spices. Longman, New York, 531.

Ranganna, S., 1997. Handbook of analysis and quality control of fruit and vegetable products, ( $4^{\text {th }} \mathrm{Edn}$.), Tata McGraw Hill, New Delhi, 1112.

Sambisavam, P.K., Girija, D., 2006. Biochemical characterization of Ralstonia solanacearum infecting ginger. Annals of Plant Protection Sciences 14(2), 419-423.

Shahid, M., Hussain, F., 2012. Chemical composition and mineral content of Zingiber officinale and Alpinia allughas (Zingiberaceae) rhizomes. International Journal of Chemical and Biochemical Sciences 2, 101-104.

Shukla, Y., Singh, M., 2007. Cancer preventive properties of ginger: a brief review. Food Chemistry Toxicology 45(5), 683-690.

Sultan, M., Bhatti, H.N., Iqbal, Z., 2005.Chemical analysis of essential oil of ginger (Zingiber officinale). Pakistan Journal of Biological Sciences 8(11), 1576-1578.

Tavakoli, N., Teimouri, R., Hamishehkar, H., 2008. Characterization and evaluation of okra gum as a tablet binder. Jundushapur Journal of Natural Pharmaceutical Products 3, 33-38.

US Pharmacopeia, National Formulary USP 23/NF 18. 2016. United States Pharmacopeial Convention. Inc., Rockville, MD. 